\title{
Understanding the Socio-Economic and Hygienic Status of Child Labourers in
}

\section{Nepal}

\author{
Joshi S K ${ }^{1}$, Shrestha $\mathrm{S}^{2}$, Shrestha R ${ }^{3}$, Vaidya $\mathrm{S}^{4}$
}

${ }^{1}$ Associate Professor, Department of Community Medicine, Kathmandu Medical College, Sinamangal, Kathmandu, Nepal

${ }^{2}$ Medical Officer, Bhimphedi Primary Health Centre, Makwanpur, Nepal

${ }^{3}$ Medical Officer, Kasthamandap Health Care Centre, Kathmandu, Nepal

${ }^{4}$ International Commission on Occupational Health (ICOH), Nepal

\begin{tabular}{l} 
Original Article \\
\hline Corresponding Author: \\
Dr. Sunil Kumar Joshi \\
Associate professor, Kathmandu Medical College, \\
Sinamangal, Kathmandu, Nepal \\
Email address: drsunilkj@gmail.com
\end{tabular}

Abstract

\section{Background}

The International Labour Organization (ILO) defines child labour as "work that deprives children of their childhood, their potential and their dignity, and that is harmful to physical and mental development. The ILO has estimated that in 2004, almost 218 million children (almost 1 in 7) aged 5-17 were involved in child labour worldwide, about 126 million under hazardous conditions. In Asian-Pacific region, 122 million children aged 5-14 were working as child labourers. It is imperative to know why the children are engaged in labour and what kind of effect child labour has in their health, education as well as the economy of their family.

\section{Methods}

This is a descriptive study which interviewed 313 child labourers working in different industries. It specially tried to assess the reasons why children joined the labour force, their family demographics, education and their general hygienic condition.

\section{Results}

83.4\% of child labourers joined labour because of poverty, $36.1 \%$ of them earned less than thousand rupees a month. $23.6 \%$ of them come from a big family with more than eight members. $30 \%$ (94) of them have not received even the primary level of education. Their overall hygienic condition is not satisfactory.

\section{Conclusion}

In Nepal, poverty is the most common cause of child labour and child labourers do not have a good hygienic condition.

Key words: Child labour, Poverty, Earnings, Hygiene

\section{Background}

The International Labour Organization (ILO) defines child labour as "work that deprives children of their childhood, their potential and their dignity, and that is harmful to physical and mental development. More specifically it involves work that is mentally, physically, socially or morally dangerous and harmful to children; and interferes with their schooling by depriving them of the opportunity to attend school; obliging them to leave school prematurely; or requiring them to attempt to combine school attendance with excessively long and heavy work $^{\prime 1}$. The ILO has estimated that in 2004, almost 218 million children (almost 1 in 7) aged 5-17 were involved in child labour worldwide, about 126 million under hazardous conditions. In AsianPacific region, 122 million children aged 5-14 were working as child labourers ${ }^{2}$.

In Nepal, in 1995/1996, 2.6 million (42\%) of the 6.2 million children aged 5-14 years were regularly working, out of which 1.7 million (26.7\%) were economically active; $83 \%$ of the later carry out unpaid work. Out of the economically active ones, 54\% were boys. Most of the child labour was noted in agriculture $(94.7 \%)^{3}$. The number was still very high in 2008 , with $33.9 \%$ of children aged 5-14 working as labourers ${ }^{4}$.

Thus, child labour is a very big obstacle ahead of us. It leaves a big and deep socio-economic gap to be filled up as the 
children who are responsible for tomorrow's nation are deprived of their basic rights. So, it is very important to know why the children are engaged in labour and what kind of effect child labour has in their health, education as well as the economy of their family.

\section{Materials and Methods}

This is a descriptive study which evaluated the socioeconomic status of child labourers - those children below 16 years of age working to earn money ${ }^{5}$, and their hygienic status. It was carried out during April and May, 2010 as a continuance of a situation analysis study that has been published elsewhere ${ }^{6}$.

First of all, a literature review was conducted where all the reports on child labour in Nepal, previously published by different national and international organizations were reviewed. On the basis of the review, 25 different work sectors which were reported to involve child labour in a large scale were selected under convenience sampling. For each sector, one specific study centre was chosen such that, in overall, they were evenly distributed in all regions of the country including the cities - Kathmandu, Biratnagar, Butwal, Nepalgunj and Mahendranagar. In each of the study centre, the employer was approached and explained about the study objectives and methods, assuring complete confidentiality. Some employers and in some cases, the parents, declined the study proposal, such work sectors were shoe factory, poultry, shoe polishing, road side circus, grocery vendors, and newspaper distribution. At the end, 19 study centres, each one representing a different work sector were agreed for the study.

At those study centres which approved the study, the child labourers were approached for interview, explaining in details about the study and its purpose. Altogether 313 children below or at the age of 16 , were approached all of whom consented to be interviewed. The interview was conducted at their work site, but in a separate room, with just the child and the interviewer, so that things could be kept private. Strict confidentiality was maintained and the children were assured that they could discontinue the interview and examination any time he or she wanted. The study was approved by the Ethical Review Committee of Kathmandu Medical College, which is affiliated to the Ethical Review Board (ERB) of Nepal Health Research Council.

The interview was based on a pre-tested questionnaire, which focused on the socio-economic factors related to child labour, and working condition in the work places and the health status of the labourers. Children above the age of 16 were excluded from the study, as they were not counted as child labourers any more 5 .

The study focused specially on the reasons behind the child to start working, his or her family demographics, his or her education, earnings and health status. For the level of education, they were grouped as illiterate if they even did not know how to read and write, literate if they know how to read and write but have not officially attended school or if they left school before they were in the first grade, primary level if they were in school lower than fifth grade and secondary level, if they were studying in grades higher than five at present or when they left school for work.

Likewise, a measure was devised to quantitatively evaluate the general hygienic condition of the child. Eight variables namely - scalp, ear, nose, mouth, teeth, skin, nail, and clothing were selected. They were evaluated on direct physical observation by the interviewers and some related questions. Two Nepal Medical Council certified medical officers conducted the examinations individually. At the end, the examination findings were tallied and a consensual observation made. The observations were categorized as:

Poor - very dirty with some kind of ulcerative lesion, discharge and foul smell along with improper development and function;

Fair - clean without any significant lesion discharge, smell and functioning well and properly developed;

Good - very clean with proper development and functioning very well and without any noted problems currently and in the past for longer duration.

Each child was assessed for those eight variables and his overall hygienic status was labelled as good, fair or poor the one which is most frequent while examining those eight variables. If one had maximum number of "goods", his hygienic status was considered good and likewise. If two labels had similar score, the better grade was taken.

\section{Results}

A total of 313 child labourers below 16 years of age were interviewed (Figure 1). Majority were male from the age group 13-16.

Figure 1: Age and sex distribution of child labourers

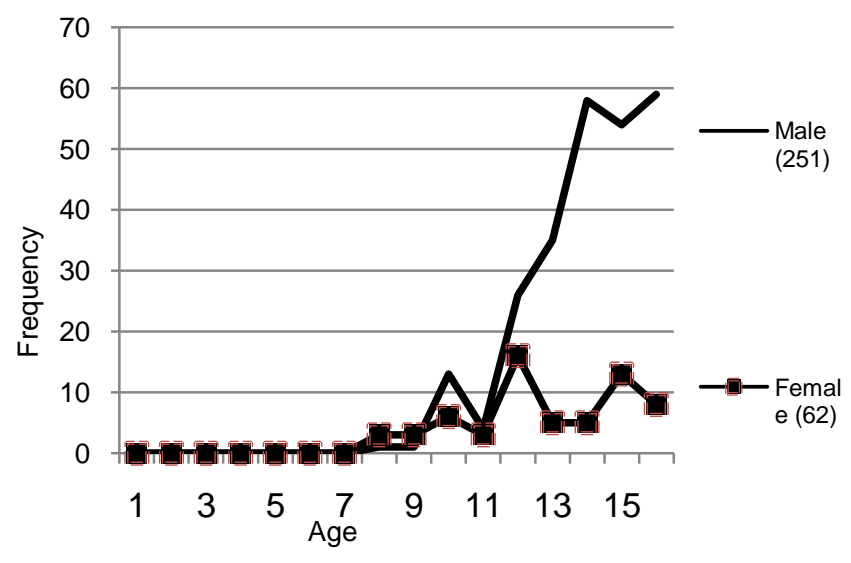

Poverty was the main reason for child-labour (Table 1). 
Table 1: Major reasons for child labour

\begin{tabular}{|l|l|l|}
\hline Reason & Number & Percentage \\
\hline Poverty & 261 & 83.4 \\
\hline Desire to earn more money & 64 & 20.4 \\
\hline Hard work at home & 22 & 7 \\
\hline Family force & 19 & 6.1 \\
\hline Broken family & 19 & 6.1 \\
\hline Not willing to study & 16 & 5.1 \\
\hline
\end{tabular}

There were other reasons that seemed unusual like hard work at home and not willing to continue study. There were more child labourers from families which are complete than from families which are not (Table 2).

\section{Table 2: Family demographics of the child labourers}

\begin{tabular}{|l|l|l|}
\hline Family & Number & Percentage \\
\hline $\begin{array}{l}\text { Both father and mother living } \\
\text { together }\end{array}$ & 225 & 71.9 \\
$\begin{array}{l}\text { Single mother } \\
\text { Single father }\end{array}$ & 27 & 8.6 \\
\hline $\begin{array}{l}\text { Divorced parents } \\
\text { Orphan }\end{array}$ & 25 & 8 \\
\hline Second marriage of the parents & 16 & 2.5 \\
\hline
\end{tabular}

Family size too seemed to have a role in promoting child labour, as relatively bigger families produce more child labourers 213 (68.1\%) (Figure 2).

Figure 2: Family size of child labourers

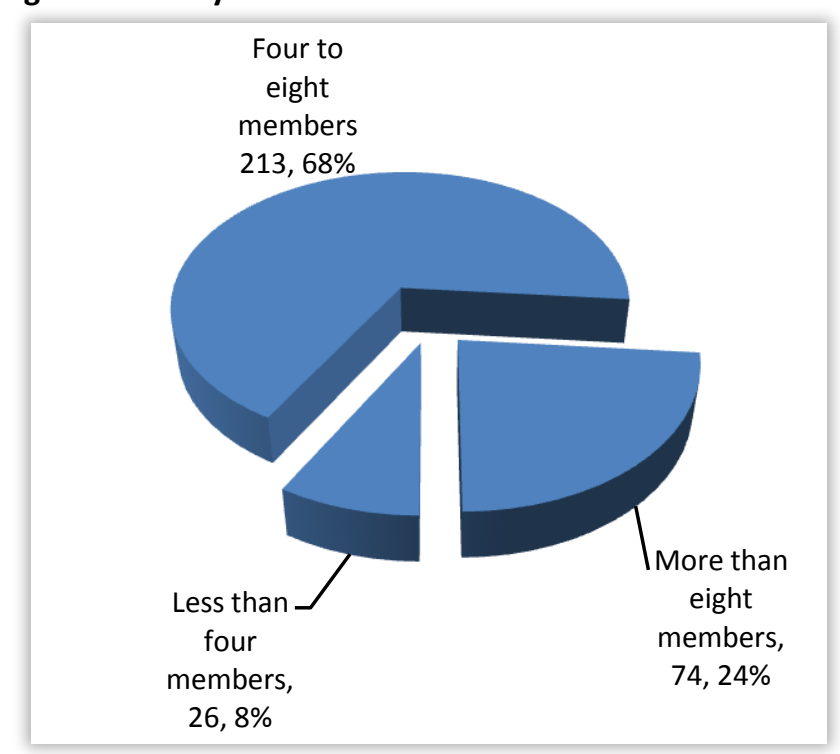

Majority of the child labourers $(160,51.1 \%)$ were primary school going children. In addition, $32,10.2 \%$ of them were illiterate and 62, 19.8\% were just literate ones, which are also disappointing figures (Figure 3 ).

Figure 3: Literacy rates and percentages across child labourers

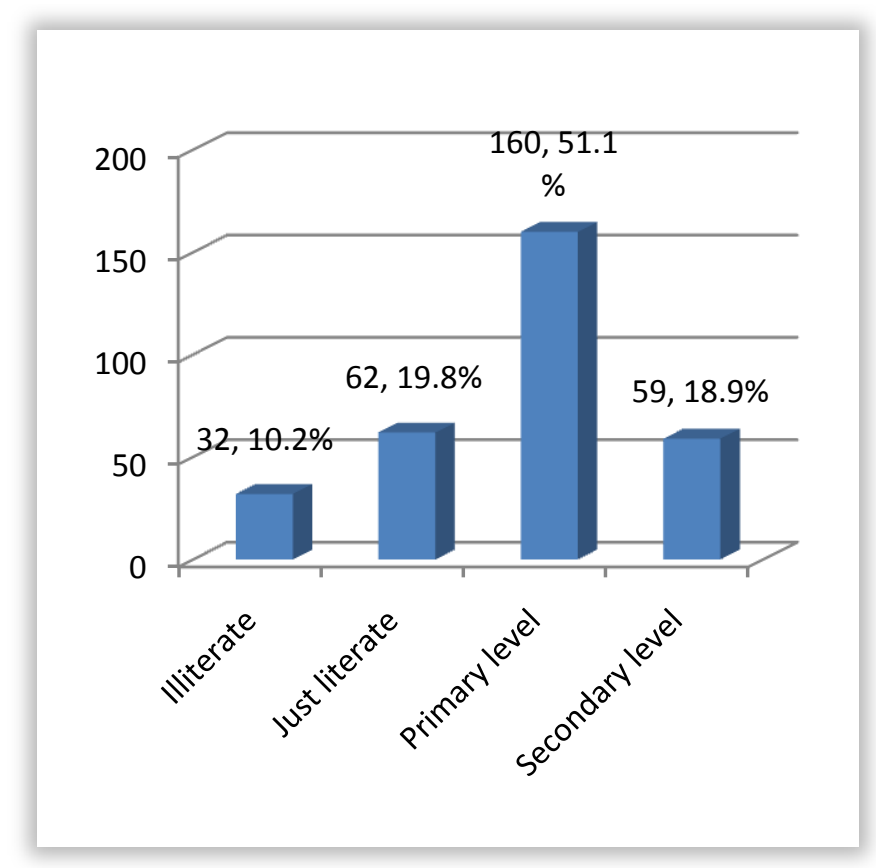

The earnings of the child-labourers were not good (Table 3 ). Majority of them $(113,36.1 \%)$ did not earn even 13 US\$ (1 US\$ $=75.7$ Nepalese rupees) a month.

\section{Table 3: Earnings of child labourers}

\begin{tabular}{|l|c|c|}
\hline $\begin{array}{l}\text { Earning in Nepalese Rupees } \\
\text { per month (US\$)* }\end{array}$ & Number & Percentage \\
\hline $\begin{array}{l}\text { Less than thousand (13 US\$) } \\
\text { In between thousand to } \\
\text { fifteen hundred (13 to 19 US\$) }\end{array}$ & 113 & 36.1 \\
$\begin{array}{l}\text { In between fifteen hundred to } \\
\text { two thousand (19 to } 26 \text { US\$) }\end{array}$ & 27 & 26.5 \\
\hline $\begin{array}{l}\text { More than two thousand } \\
\text { (more than 26 US\$) }\end{array}$ & 66 & 21.1 \\
\hline
\end{tabular}

*The conversion rate used is 1 US\$ $=75.7$ Nepalese rupees (NPR)

Majority of them $(135,47 \%)$ got paid every month, while there were 79 (28\%) who got paid everyday for the amount they worked. Some got paid depending on the number of goods they prepare. Like, in embroidery works, wood works and metal works they got paid equal to the number of embroideries they prepare or a number of sculptures they make (Figure 4). 


\section{Figure 4: Wages of child labourers}

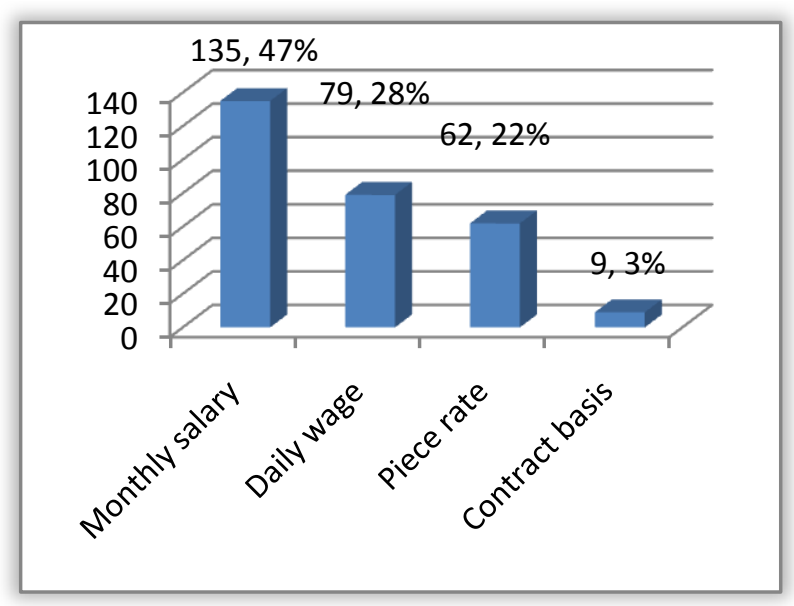

Table 4: Hygiene status of child labourers

\begin{tabular}{|c|c|c|c|c|}
\hline Work sector & Poor (\%) & Fair (\%) & $\begin{array}{l}\text { Good } \\
(\%)\end{array}$ & Total \\
\hline Agriculture & $3(15)$ & $5(25)$ & $12(60)$ & 20 \\
\hline Hotel and restaurant & $9(32.1)$ & $14(50)$ & $5(17.9)$ & 28 \\
\hline Carpet & $1(10)$ & $9(90)$ & $0(0)$ & 10 \\
\hline Brick kilns & $4(100)$ & $0(0)$ & $0(0)$ & 4 \\
\hline $\begin{array}{l}\text { Overland } \\
\text { transportations }\end{array}$ & $12(35.3)$ & $22(64.7)$ & $0(0)$ & 34 \\
\hline $\begin{array}{l}\text { Vehicle repair and } \\
\text { services }\end{array}$ & $6(12.5)$ & $23(47.9)$ & 19(39.6) & 48 \\
\hline Construction works & $2(12.5)$ & $12(75)$ & $2(12.5)$ & 16 \\
\hline Stone crushing & $16(55.2)$ & $13(44.8)$ & $0(0)$ & 29 \\
\hline $\begin{array}{l}\text { Scavenging and rag } \\
\text { picking }\end{array}$ & $15(57.7)$ & $11(42.3)$ & $0(0)$ & 26 \\
\hline Portering & $6(46.2)$ & $7(53.8)$ & $0(0)$ & 13 \\
\hline Domestic works & $0(0)$ & $14(50)$ & $14(50)$ & 28 \\
\hline $\begin{array}{l}\text { Metal casting and } \\
\text { finishing }\end{array}$ & $4(50)$ & $4(50)$ & $0(0)$ & 8 \\
\hline Metal works & $0(0)$ & 10(90.9) & $1(9.1)$ & 11 \\
\hline Embroidering & $1(20)$ & $4(80)$ & $0(0)$ & 5 \\
\hline Wood works & $1(8.3)$ & $9(75)$ & $2(16.7)$ & 12 \\
\hline Painting & $1(16.7)$ & $6(83.3)$ & $0(0)$ & 7 \\
\hline Hair cut & $0(0)$ & $1(33.3)$ & $2(66.7)$ & 3 \\
\hline $\begin{array}{l}\text { Tyre treading and } \\
\text { resoling }\end{array}$ & $0(0)$ & $1(50)$ & $1(50)$ & 2 \\
\hline Beverage factories & $0(0)$ & $3(33.3)$ & $6(66.7)$ & 9 \\
\hline Total & $81(25.9 \%)$ & $168(53.7 \%)$ & 64 (20.4\%) & 313 \\
\hline
\end{tabular}

Majority of the child labourers do not have proper hygienic status (Table 4).

Only $64(20.4 \%)$ of them were found to be in good hygiene. Eighty one (25.9\%) of them were in poor hygienic condition and the rest 168 (53.7\%) were in between, barely satisfactory. Stone crushing, Scavenging and rag picking were the worst among the works with 16 of total 29 and 15 of 26 children respectively in poor hygienic condition and none in good hygiene.

Nepal Journal of Epidemiology 2011;1(3): 90-94
Likewise, vehicle repair and services and domestic works seemed to have better hygienic status with 19(39.6\%) and $14(50 \%)$ children respectively with good hygiene.

\section{Discussion}

Thus, poverty seems to be driving children to work for even as less as a thousand rupees (13 US\$ at 1 US\$ = 75.7 NPR) a month, which even does not seem to help much. Instead, this would make the family to send their other children too to work with an intention to earn enough. To make things worse, the hygienic condition of the working children is not satisfactory.

With $33.9 \%$ of children working as labourers, Child labour is indeed a big problem for $\mathrm{Nepal}^{4}$. The situation is similar in other developing countries like Bangladesh where 4.7 (13.4\%) of children aged 5-14 worked as child labourers in $2003 / 2004^{7}$. Likewise, the number was around 2.5 million in Pakistan $(1999 / 2000)^{8}$, and 0.48 million in Sri Lanka (1999) ${ }^{9}$.

The study found that poverty, child labour and education have a very intense relation. Majority of children joined labour because of poverty. This would deprive them of education, either because they do not have time for school or they could not afford education. Thus, $(94,30 \%)$ of the study participants could not ever go to school. Due to low education, they could never have a decent, economically stable future, which will make it impossible for their offspring to get proper education and the vicious cycle just continues. A previous survey also showed that $14.5 \%$ of the working boys and $25.9 \%$ of working girls did not go to school $^{10}$. Likewise, another study on rag pickers in Nepal also showed that $51 \%$ of them were illiterate, but it did not comment on the education status of the literate ones ${ }^{11}$.

The study also tried to see if poverty is what's been driving child labour, has it helped reduce poverty then? Looking at how much the children earned, it was found child labour did not help to reduce poverty. More than $36 \%$ of child labourers earn less than 13 US\$ ( 1 US\$ = 75.7 NPR) a month, which is a very small amount. An earlier study in 2001 also found that over $50 \%$ of domestic child workers in Kathmandu do not get paid. Among those who got paid, almost $40 \%$ get paid less than 60 US\$ a year ${ }^{12}$. Thus, the situation has not improved much. Next, it is the children and their family, who need job; they cannot complain for better salary. They cannot fight legally because child labour is against the law and any legal complain means loss of their job. So, though their earning is very less, they do not seem to have a way out.

Among other reasons behind child labour, hard work at home seems a quite unusual one. Usually household works are not considered as child labour. But, sometimes they can be worse because no one is bothered about it and on the top; the child does not get paid. In such conditions, it is likely that the child runs away from home and join any other form of labour where he at least gets paid. Some previous studies have also reported that civil war and illiteracy of the parents are also some causes of child labour ${ }^{10}$. At the present post 
civil war situation, the conflict as a cause of child labour does not make much sense though.

It is usually expected that as long as the parents are alive and together, they would work and support the family, the child would not have to work. But, contrary to this, it was found that most of the child labourers came from families which had both the father and the mother. A previous study on domestic child workers in Nepal also found the same conclusion where $72 \%$ of the child workers had a complete family with both father and mother alive ${ }^{11}$. Another study on rag pickers also had similar findings, $60 \%$ of them had complete family ${ }^{11}$. But, family size definitely influenced child labour as we found majority of child labourers come from bigger families. It is very straight forward that bigger the families, bigger their expenses and thus, more should be the income. And, the way of income would be to get the children to work. Similar finding was reported in the $1995 / 1996$ survey where majority of the working children came from families larger than five members ${ }^{3}$. The study among rag pickers also had similar findings where the average family size was 5.4 and 137 (45.6\%) of them had family size larger than five members ${ }^{11}$.

Likewise, the overall hygienic status of child workers is not satisfactory. As shown earlier, stone crushing, scavenging and rag picking were the most unhygienic ones. This is reasonable looking into the physical conditions where they have to work - dumping sites, road sides where piles of garbage and wastes are deposited. What is more important is the influence of hygienic condition in the economy of these child labourers. They work even among such hazards just to earn some money, but due to poor hygiene, they are very likely to fall sick which means - absence from work and additional expenditure for treatment. Thus, hygiene needs special care and attention.

In overall, the study provides a general outlook of child labour and its different aspects. Any setback in the study could be those six industries which could not be included in the study and the fact that only one work place or industry was chosen for each work sector, which definitely cannot represent that work sector as a whole. But, we believe they do not make any difference in our study, because, our purpose was not to find out the prevalence of child labour or the number of child work places or any comparison between those work places. We were concerned more with the child labourers and their socio economic status rather than their number or work places. That is why we took only one sample industry for each work sector, just to make sure we get child labourers from all the sectors.

\section{Conclusion}

Child labour stands like a big stigma to our nation. Poverty is the main factor driving more and more children to labour, which then leads to compromise in their education and their future as well. Although children work hard and long hours, they do not get paid well and their general hygienic condition is not satisfactory.

\section{References}

1. International Labour organization. International programme on the elimination of child labour. About child labour. [Online] 2009 [Cited 2010 Nov 13]. Available from: URL: http://www.ilo.org/ipec/facts/ lang--en/index.htm

2. International labour organization. Facts on child labour - 2006. Geneva: Department of communication and public information, ILO; 2006.

3. Suwal BR, KC BK, Adhikari KP. Child labour situation in Nepal. Report from migration and employment survey, 1995/96. Kathmandu: Tribhuvanuniversity; 1997.

4. Central bureau of statistics. Executive summary, Nepal labour force survey 2008. Kathmandu: CBS; 2008.

5. National legislation, Nepal. The children's act, 1992.

6. Joshi SK, Sharma SC, Shrestha S. Child labour and associated hazards - a descriptive study. Asian-Pacific Newslett on Occup Health and Safety 2009;16:66-9.

7. International programme on the elimination of child labour. Bangladesh child labour data country brief. Geneva: ILO; 2003.

8. Zaidi HH, Beg MA, Pervaiz K, Saddiqi IH, Shah GH. Baseline survey report on child labour in Kasur Tanneries. Geneva: ILO; 2004. p. 17.

9. International programme on the elimination of child labour. Sri Lanka child labour data country brief. Geneva: ILO; 2003.

10. International programme on the elimination of child labour. Child labour and responses. Geneva: ILO; November 2004.

11. KC BK, Gurung YB, Adhikari KP, Subedi G. Investigating the worst forms of child labour No. 4. Nepal Situation of child Rag pickers: A rapid assessment. Kathmandu: Central Department of population studies, TU, WHO/Nepal; 2001.

12. Sharma S, Thakurathi M, Sapkota K, Devkota B, Rimal B. Investigating the worst forms of child labour No. 3. Nepal situation of Domestic child labourers in Kathmandu: A rapid assessment. Geneva: WHO; 2001. 